\title{
Acuariidae (Nematoda) in Procellariiformes (Aves) on the southern coast of Rio Grande do Sul, Brazil
}

\author{
Acuariidae (Nematoda) em Procellariiformes (Aves) no litoral sul do Rio Grande do Sul, Brasil \\ Camila Costa Schramm ${ }^{1 *}$; Carolina Silveira Mascarenhas ${ }^{1}$; Silvia Bainy Gastal² ${ }^{2}$ Simone Scheer ${ }^{1}$ Gertrud Müller $^{1}$; \\ Ricardo Berteaux Robaldo ${ }^{3}$

\begin{abstract}
${ }^{1}$ Laboratório de Parasitologia de Animais Silvestres - LAPASIL, Departamento de Microbiologia e Parasitologia, Instituto de Biologia, Universidade Federal de Pelotas - UFPel, Campus Universitário Capão do Leão, Pelotas, RS, Brasil

${ }^{2}$ Centro de Recuperaçáo de Animais Marinhos - CRAM, Museo Oceanográfico Prof. Eliézer de Carvalho Rios, Universidade Federal de Rio Grande - FURG, Rio Grande, RS, Brasil

${ }^{3}$ Laboratório de Fisiologia Aplicada a Aqüicultura, Instituto de Biologia, Universidade Federal de Pelotas - UFPel, Campus Universitário Capão do Leão, Pelotas, RS, Brasil
\end{abstract}

Received August 3, 2017

Accepted November 21, 2017

\begin{abstract}
Acuariidae nematodes are normally found in the digestive tract of aquatic birds, including Procellariiformes. Were examined Calonectris borealis $(\mathrm{n}=4)$, Diomedea exulans $(\mathrm{n}=1)$, Macronectes giganteus $(\mathrm{n}=8)$, Thalassarche chlororhynchos $(\mathrm{n}=5)$, Thalassarche melanophrys $(\mathrm{n}=15)$, Procellaria aequinoctialis $(\mathrm{n}=4)$, Puffinus gravis $(\mathrm{n}=2)$ and Puffinus puffinus $(\mathrm{n}=6)$, collected on the southern coast of RS, Brazil. A total of 16 birds $(35.5 \%)$ were parasitized by two species of Acuariidae. Stegophorus diomedeae and Seuratia shipleyi were identified, with prevalences of $26.1 \%$ and $21.7 \%$, respectively. Few studies on nematodes in Procellariiformes have been conducted. Here, the acuariids Seuratia shipleyi in Calonectris borealis and Procellaria aequinoctialis and Stegophorus diomedeae in Diomedea exulans, Procellaria aequinoctialis and Thalassarche chlororhynchos were reported for the first time.
\end{abstract}

Keywords: Nematoda, albatrosses, petrels, parasites, prevalence, infection rates.

\section{Resumo}

Os nematoides Acuariidae são normalmente encontrados no trato digestivo de aves aquáticas, incluindo os Procellariiformes. Foram examinadas Calonectris borealis $(\mathrm{n}=4)$, Diomedea exulans $(\mathrm{n}=1)$, Macronectes giganteus $(\mathrm{n}=8)$, Thalassarche chlororhynchos $(\mathrm{n}=5)$, Thalassarche melanophrys $(\mathrm{n}=15)$, Procellaria aequinoctialis $(\mathrm{n}=4)$, Puffinus gravis $(\mathrm{n}=2)$ e Puffinus puffinus $(\mathrm{n}=6)$, coletados na costa sul do Rio Grande do Sul, Brasil. Dentre os exemplares examinados, 16 (35,5\%) estavam parasitados por duas espécies de Acuariidae. Foram identificados Stegophorus diomedeae e Seuratia shipleyi, com prevalência de 26,1\% e 21,7\%, respectivamente. Existem poucos estudos relacionados a nematoides em Procellariiformes, e aqui registra-se pela primeira vez os Acuariidae Seuratia shipleyi em Calonectris borealis e Procellaria aequinoctialis, e Stegophorus diomedeae em Diomedea exulans, Procellaria aequinoctialis e Thalassarche chlororhynchos.

Palavras-chave: Nematoda, albatrozes, petréis, parasitos, prevalência, intensidade média.

\section{Introduction}

Acuariidae include midsized nematodes that inhabit the upper digestive tract of aquatic birds (Procellariiformes, Pelecaniformes, Ciconiiformes, Anseriformes, Charadriiformes and Coraciiformes), although a few are associated with terrestrial birds such as Falconiformes, Galliformes and Passeriformes (ANDERSON, 2000).

${ }^{*}$ Corresponding author: Camila Costa Schramm. Departamento de Microbiologia e Parasitologia, Instituto de Biologia, Universidade Federal de Pelotas - UFPel, CP 354, CEP 96010-900, Pelotas, RS, Brasil. e-mail: cacschramm@gmail.com
The species of this subfamily are characterized by the presence of cephalic cords as fixation structures (CHABAUD, 2009).

Over the life cycle of acuariids, it has been observed that larvae in the infective stage are encapsulated in the intestine or mesentery of paratenic hosts (frog or fish) to reach the final host. However, some nematodes undergo all their developmental stages within the gizzard of the definitive host, where the adults are found, while others first develop to the subadult stage in the proventriculus before migrating to the gizzard. Some esophageal parasites develop entirely in the esophagus, while others reach 
the subadult stage in the proventriculus before parasitizing the esophagus. Proventricular nematodes probably undergo their entire development in this organ, and some of these species occur in seabirds. On the migration routes used by these birds, ingestion of shellfish that are intermediate hosts can contribute towards the diversity of acuariids that infect birds (ANDERSON, 2000).

Acuariidae comprises Acuariinae, Schistorophinae and Seuratiinae. The subfamily Seuratiinae comprises seven genera, among which are Stegophorus and Seuratia, commonly found parasitizing seabirds in different regions (Table 1).

Procellariiformes are widely distributed seabirds, but with greater diversity of species in the southern hemisphere. This order consists of 99 species divided into four families: Procellariidae, Hydrobatidae, Pelecanoididae and Diomedeidae (SICK, 1997; IBAMA, 2006). These are predatory birds at the top of the food chain and they generally require productive waters to ensure their survival and reproduction (CURY et al., 2011). Their diet consists of squid, krill, fish, carcasses and chicks of other birds. These birds also often follow fishing boats in search of debris that has been in the sea for a long time (BARBIERI, 2008; CUBAS et al., 2014.). Presence of seabirds of the order Procellariiformes is indicative of the presence of fish shoals and hence of ecosystem health. Presence/absence of prey is reflected in changes to these birds' diet (CUBAS et al., 2014).

The coast of Rio Grande do Sul, in southern Brazil, is an important feeding site for several species of seabirds. One factor responsible for this large concentration of birds is high biological productivity, especially in winter, when a coastal branch of the Falkland current enters, bearing cold water rich in organic matter from the south (PEREZ, 2012).
Considering the ecological importance of these birds, the conservation condition of these species and the lack of information about their biology and helminth fauna, the aim of the present study was to report on occurrences of the acuariid nematodes Stegophorus diomedeae and Seuratia shipleyi as parasites of Procellariiformes on the southern coast of Rio Grande do Sul, and the infection rates in these birds.

\section{Materials and Methods}

A total of 45 specimens of Procellariiformes were examined, collected from the southern coast of Brazil between Farol de Mostardas ( $31^{\circ} 14^{\prime}$ S; $50^{\circ} 54^{\prime} \mathrm{W}$ ) and Barra do Chui (33 44' S; $\left.53^{\circ} 22^{\prime} \mathrm{W}\right)$. Most of them $(\mathrm{n}=32)$ were received from the Centro de Recuperação de Animais Marinhos (CRAM-FURG), where they had died during the rehabilitation process. Nine hosts were found dead on beaches and four individuals were caught through longline fisheries. The host species examined were Calonectris borealis $(\mathrm{n}=4)$, Diomedea exulans $(\mathrm{n}=1)$, Macronectes giganteus $(\mathrm{n}=8)$, Thalassarche chlororhynchos $(\mathrm{n}=5)$, Thalassarche melanophrys $(\mathrm{n}=15)$, Procellaria aequinoctialis $(\mathrm{n}=4)$, Puffinus gravis $(\mathrm{n}=2)$ and Puffinus puffinus ( $\mathrm{n}=6)$.

The esophagus, proventriculus, ventricle, small intestine, large intestine, cecum and cloaca of the birds were examined separately during the necropsy. The nematodes were fixed in AFA $\left(70^{\circ} \mathrm{GL}\right.$ ethanol, 37\% formalin and glacial acetic acid, in the proportions 95:3:2) and preserved in $70^{\circ} \mathrm{GL}$ ethanol that was $10 \%$ glycerinated (AMATO \& AMATO, 2010). After clarification in Amann's lactophenol, the nematodes were mounted on semi-permanent

Table 1. Species of Seuratiinae (Nematoda: Acuariidae) recorded in birds, according to host collection site, with the respective bibliographical references.

\begin{tabular}{|c|c|c|c|}
\hline Seuratiinae & Host & Host collection location & Reference \\
\hline \multirow[t]{3}{*}{ Seuratia shipleyi } & Thalassarche melanophrys (Procellariiformes) & Rio de Janeiro (Brazil) & Mendonça \& Rodrigues (1968) \\
\hline & Puffinus gravis (Procellariiformes) & Gough Island (South Atlantic) & Hoberg \& Ryan (1989) \\
\hline & Phoebetria palpebrata (Procellariiformes) & Antarctica & Barbosa \& Palácios (2009) \\
\hline \multirow[t]{2}{*}{ Stegophorus diomedeae } & $\begin{array}{l}\text { Thalassarche melanophrys } \\
\text { (Procellariiformes) }\end{array}$ & Rio de Janeiro (Brazil) & Rodrigues \& Mendonça (1967) \\
\hline & Puffinus gravis (Procellariiformes) & Florida (USA) & Foster et al. (1996) \\
\hline Stegophorus stellaepolaris & Puffinus gravis (Procellariiformes) & Florida (USA) & Foster et al. (1996) \\
\hline \multirow[t]{7}{*}{ Stegophorus macronectes } & Pygoscelis papua (Sphenisciformes) & Antarctica & Barbosa \& Palácios (2009) \\
\hline & Pygoscelis adeliae (Sphenisciformes) & & \\
\hline & Eudyptes chrysocome (Sphenisciformes) & & \\
\hline & Eudyptes chrysolophus (Sphenisciformes) & & \\
\hline & Macronectes giganteus (Procellariiformes) & & \\
\hline & Chionis albus (Charadriiformes) & & \\
\hline & Pygoscelis antarcticus (Sphenisciformes) & Antarctica & Vidal et al. (2015) \\
\hline Stegophorus arctowski & Macronectes giganteus (Procellariiformes) & Antarctica & Barbosa \& Palácios (2009) \\
\hline \multirow[t]{4}{*}{ Stegophorus heardi } & Oceanites oceanicus (Procellariiformes) & Antarctica & Barbosa \& Palácios (2009) \\
\hline & Pelecanoides georgicus (Procellariiformes) & & \\
\hline & Pelecanoides urinatrix (Procellariiformes) & & \\
\hline & Catharacta lonnbergi (Charadriiformes) & & \\
\hline \multirow[t]{2}{*}{ Stegophorus stercorarii } & $\begin{array}{l}\text { Cerorhinca monocerata } \\
\text { (Charadriiformes) }\end{array}$ & Japan & Yoshimo et al. (2015) \\
\hline & $\begin{array}{l}\text { Synthliboramphus antiquus } \\
\text { (Charadriiformes) }\end{array}$ & & \\
\hline
\end{tabular}


slides and identified in accordance with Mendonça \& Rodrigues (1968), Rodrigues \& Mendonça (1967) and Chabaud (2009).

The parasitological indexes, i.e. prevalence, mean intensity of infection (MII), mean abundance (MA) and range of infection (R), were calculated in accordance with Bush et al. (1997). Photomicrographs were taken using an Olympus BX 41 microscope coupled to a digital camera system. Representative specimens of nematodes were deposited in the "Coleção de Helmintos do Laboratório de Parasitologia de Animais Silvestres da Universidade Federal de Pelotas (LAPASIL/UFPel)" Rio Grande do Sul, Brazil, under no CHLAPASIL 682-684.

\section{Results}

Out of the total of 45 hosts examined, 16 (35.5\%) were parasitized by acuariid helminths. Seuratia shipleyi Stossich, 1900, and Stegophorus diomedeae Johnston and Mawson, 1942 (Figure 1), were identified with prevalences of $26.1 \%$ and $21.7 \%$, respectively (Table 2 ).

Seuratia shipleyi had greatest mean intensity of infection and mean abundance in $P$. gravis (MII $=39$ helminths/host and MA = 19.5), while Stegophorus diomedeae showed highest rates in D. exulans $(\mathrm{MII}=28$ helminths/host and $\mathrm{MA}=28)$. However, only
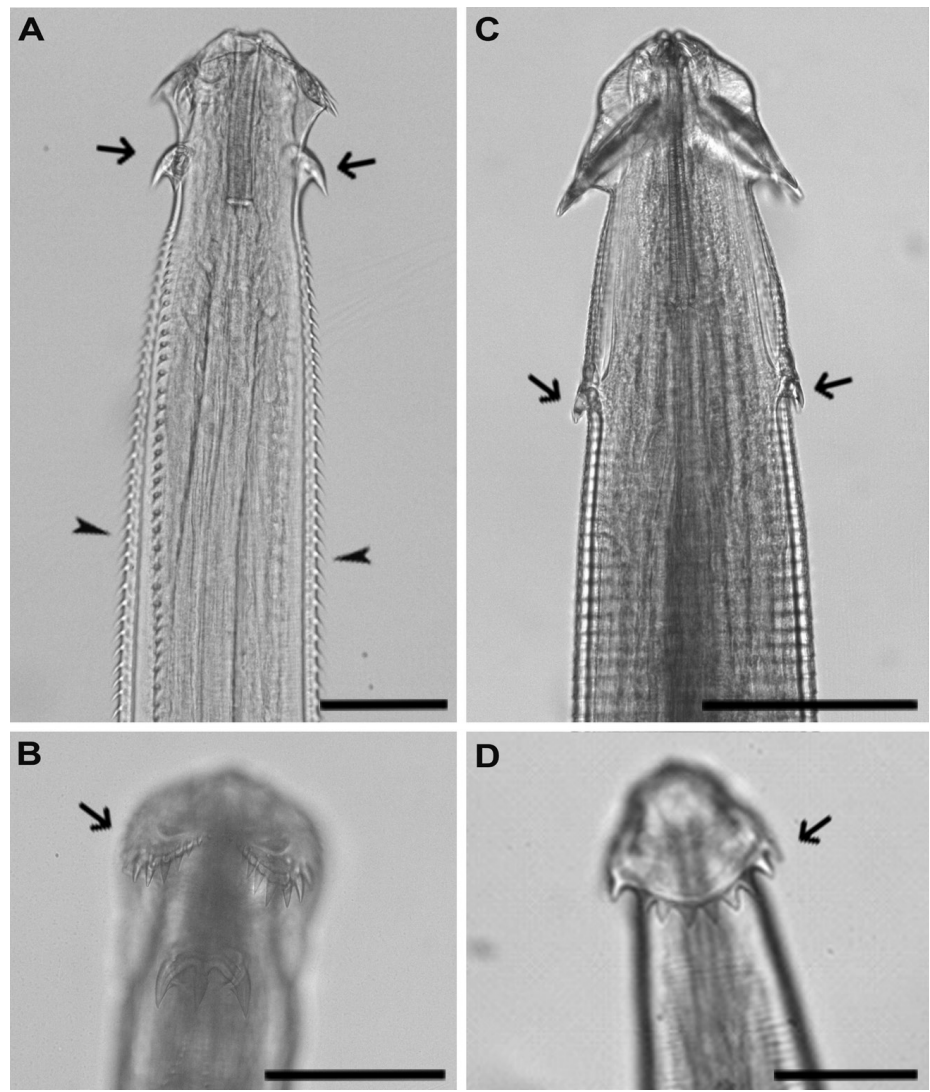

Figure 1. Seuratiinae (Acuariidae: Nematoda) parasite of Procellariiformes (Aves) on the southern coast of Rio Grande do Sul, Brazil. (A-B) Seuratia shipleyi parasite of Puffinus puffinus, (A) Ventral view, the arrows show the cervical papillae and the arrowheads show the row of spines $(\mathrm{Bar}=142,5 \mu \mathrm{m})$; (B) Lateral view, the arrow show the hood $(\mathrm{Bar}=150 \mu \mathrm{m})$; (C-D) Stegophorus diomedeae parasite of Diomedea exulans, (C) Ventral view, the arrows show the cervical papillae $(\operatorname{Bar}=132,5 \mu \mathrm{m})$; (D) Lateral view, the arrow show the hood $(\mathrm{Bar}=85 \mu \mathrm{m})$.

Table 2. Prevalence (P\%), mean intensity of infection (MII), mean abundance (AM) and range of infection (R) of Seuratia shipleyi and Stegophorus diomedeae (Nematoda: Acuariidae) in Procellariiformes $(\mathrm{n}=45)$, Rio Grande do Sul, Brazil.

\begin{tabular}{|c|c|c|c|c|c|c|c|c|}
\hline \multirow{2}{*}{ Host } & \multicolumn{2}{|c|}{ Seuratia shipleyi } & \multirow{2}{*}{ MA } & \multirow{2}{*}{$\mathbf{R}$} & \multicolumn{2}{|c|}{ Stegophorus diomedeae } & \multirow{2}{*}{ MA } & \multirow{2}{*}{$\mathbf{R}$} \\
\hline & $\mathbf{P} \%$ & MII & & & $\mathbf{P} \%$ & MII & & \\
\hline Procellariiformes $(\mathrm{n}=45)$ & 26.1 & 7.8 & 2.0 & $1-37$ & 21.7 & 5.2 & 1.1 & $1-24$ \\
\hline Calonectris borealis $(\mathrm{n}=4)$ & 100.0 & 1.0 & 7.5 & $1-22$ & - & - & 0 & - \\
\hline Diomedea exulans $(\mathrm{n}=1)$ & - & - & 0 & - & 100.0 & 28.0 & 28.0 & 24 \\
\hline Macronectes giganteus $(\mathrm{n}=8)$ & - & - & 0 & - & 25.0 & 2.0 & 0.5 & 2 \\
\hline Thalassarche chlororhynchos $(\mathrm{n}=5)$ & - & - & 0 & - & 20.0 & 4.0 & 0.8 & 4 \\
\hline Thalassarche melanophrys $(\mathrm{n}=15)$ & 13.3 & 1.5 & 0.6 & $1-2$ & 6.6 & 2.0 & 0.1 & 2 \\
\hline Procellaria aequinoctialis $(\mathrm{n}=4)$ & 25.0 & 1.0 & 0.2 & 1 & 25.0 & 1.0 & 0.2 & 1 \\
\hline Puffinus gravis $(\mathrm{n}=2)$ & 50.0 & 39.0 & 19.5 & $2-37$ & 50.0 & 7.0 & 3.5 & 7 \\
\hline Puffinus puffinus $(\mathrm{n}=6)$ & 50.0 & 7.0 & 3.5 & $3-14$ & 50.0 & 2.3 & 1.2 & $1-4$ \\
\hline
\end{tabular}


a few hosts belonging to this species were examined. In contrast, in T. melanophrys $(\mathrm{n}=15)$, the MII and MA for both acuariid species showed low values (Table 2).

Coinfection between the two acuariids was observed in four individuals (8.9\% of the hosts): three specimens of Puffinus puffinus and one of $P$. aequinoctialis. In P. puffinus, it was observed that in the birds coinfected with these two species, $S$. shipleyi had higher mean intensity than $S$. diomedeae.

\section{Discussion and Conclusion}

Most of the studies that have reported Acuariidae in Procellariiformes have dealt with records of these helminths in different hosts and have generally only presented the prevalence index (HOBERG \& RYAN, 1989; FOSTER et al., 1996). Similarly, there have been few studies on occurrences of coinfection between acuariid helminths (MENDONÇA \& RODRIGUES, 1968; RODRIGUES \& MENDONÇA, 1967).

Mendonça and Rodrigues (1968) and Rodrigues and Mendonça (1967) observed S. shipleyi and S. diomedeae in the proventriculus of a specimen of T. melanophrys, thus indicating that coinfection with these acuariids was present.

Hoberg \& Ryan (1989) examined the gastrointestinal tract of P. gravis and identified S. shipleyi in the proventriculus of five birds (25\%). (FOSTER et al. 1996) examined 15 specimens of $P$. gravis, from Florida, and reported S. shipleyi in the proventriculus and Stegophorus stellaepolaris and $S$. diomedeae in the ventricle, with prevalences of $60 \%, 20 \%$ and $93 \%$, respectively. However, they did not report any data on coinfection.

Spotorno et al. (2005) examined 51 specimens of Procellariiformes that were found dead on Cassino beach ( $\left.32^{\circ} 22^{\prime} \mathrm{S} ; 52^{\circ} 18^{\prime} \mathrm{W}\right)$, in Rio Grande do Sul. They reported that $47 \%$ were infected with nematodes, and observed injuries in the proventriculus caused by Seuratia spp. in Macronectes giganteus, they reported ulcers, epithelial and gastric gland injuries and cell necrosis in the proventriculus. In Macronectes halli, presence of Seuratia spp. was associated with granuloma in the mucosa of the proventriculus. These authors commented that the damage caused by these nematodes might, in some cases, cause infection by bacteria, thus indirectly leading these birds' death. Barbosa \& Palacios (2009) listed the parasites from seabirds and cited Seuratia and Stegophorus parasitizing various Charadriiformes, Procellariiformes and Sphenisciformes, but did not report the infection rates.

La Sala et al. (2012) examined 103 specimens of Larus atlanticus (Charadriiformes) in Argentina between 2005 and 2006. They found the acuariids Pectinospirura argentata, Sciadiocara sp. and Skrjabinoclava andersoni parasitizing the proventriculus of these hosts, with prevalence and mean intensity of $80.3 \%$ and 23.7 helminths/infected host, and $89.2 \%$ and 50.8 helminths/infected host, in 2005 and 2006, respectively. Mild inflammation in the proventriculus was caused by these nematodes because of their mucosal adherence and associated ulcerations.

This is the first record of parasitological indexes for both of these species of Acuariidae, Seuratia shipleyi and Stegophorus diomedeae, in Procellariiformes in Rio Grande do Sul, southern Brazil. It was observed that these helminths have low host specificity, since they occur not only in various species of Procellariiformes but also in Charadriiformes and Sphenisciformes. Regarding knowledge of helminth diversity in Procellariiformes, $S$. shipleyi is reported for the first time in Calonectris borealis, Procellaria aequinoctialis, Puffinus gravis and likewise, Stegophorus diomedeae in Diomedea exulans, P. aequinoctialis, Thalassarche chlororhynchos, Macronectes giganteus and Puffinus puffinus.

\section{Acknowledgements}

Special thanks to CAPES (Coordenação de Aperfeiçoamento do Pessoal de Nível Superior) for funding (procedural no. 032/2010).

\section{References}

Amato J F R, Amato SB. Técnicas gerais para coleta e preparação de helmintos endoparasitas de aves. In: Von Matter S, Straube FC, Piacentini VQ, Accordi JA, Cândido JF Jr. Ornitologia e conservaçâo - ciência aplicada, técnicas de pesquisa e levantamento. Rio de Janeiro: Technical Books; 2010. p. 367-394.

Anderson RC. Nematode parasites of vertebrates: their development and transmission. 2nd ed. Oxon: CABI Publishing; 2000.

Barbieri E. Os albatrozes: desajeitados em terra, mas ágeis no ar [online] 2008. [cited 2015 June 9]. Available from: ftp://ftp.sp.gov.br/ftppesca/ albatrozes.pdf

Barbosa A, Palacios MJ. Health of antarctic birds: a review of their parasites, pathogens and diseases. Polar Biol 2009; 32(8): 1095-1115. http://dx.doi.org/10.1007/s00300-009-0640-3.

Bush AO, Lafferty KD, Lotz JM, Shostak AW. Parasitology meets ecology on its own terms: Margolis et al. revisited. J Parasitol 1997; 83(4): $575-$ 583. PMid:9267395. http://dx.doi.org/10.2307/3284227.

Chabaud AG. Spiruroidea, habronematoidea and acuarioidea. In: Anderson RC, Chabaud AG, Willmott S. Keys to the nematode parasites of vertebrates. Paris, France: CABI; 2009. p. 361-390.

Cubas ZS, Ramos Silva JC, Catão-Dias JL. Tratado de animais selvagens - medicina veterinária. 2. ed. Sáo Paulo: Roca, 2014.

Cury PM, Boyd IL, Bonhommeau S, Anker-Nilssen T, Crawford RJM, Furness RW, et al. Global seabird response to forage fish depletion-onethird for the birds. Science 2011; 334(6063): 1703-1706. PMid:22194577. http://dx.doi.org/10.1126/science.1212928.

Foster GW, Kinsella JM, Price RD, Mertins JW, Forrester DJ. Parasitic helminths and arthropods of Greater Shearwaters (Puffinus gravis) from Florida. J Helminthol Soc Wash 1996; 63(1): 83-88.

Hoberg EP, Ryan PG. Ecology of helminth parasitism in Puffinus gravis (Procellariiformes) on the breeding grounds at Gough Island. Can J Zool 1989; 67(1): 220-225. http://dx.doi.org/10.1139/z89-030.

Instituto Brasileiro de Meio Ambiente e dos Recursos Naturais Renováveis - IBAMA. Plano Nacional para Conservação de Albatrozes e Petréis [online]. 2006 [cited 2015 May 29]. Available from: http://www. icmbio.gov.br/portal/images/stories/docs-plano-de-acao/pan-albatrozes/ albatrozes-parte1.pdf

La Sala LF, Smits J, Martorelli SR. Enteric Infections by Trematodes and Nematodes in Olrog's Gull, Larus atlanticus. Avian Dis 2012; 56(4): 764 767. PMid:23397854. http://dx.doi.org/10.1637/10251-052112-Case.1. 
Mendonça JM, Rodrigues H. Redescrição de Stegophorus diomedeae (Johnston \& Mawson, 1942) Johnston \& Mawson, 1945 (Nematoda, Spiruroidea). Mem Inst Oswaldo Cruz 1968; 65(2): 149-152.

Perez MS. Análise do conteúdo do trato digestório de Puffinus puffinus (Brünninch, 1764) (Procellariiformes), no litoral norte e médio leste do Rio Grande do Sul, Brasil [monografia]. Imbé: Universidade Federal do Rio Grande do Sul; 2012.

Rodrigues H, Mendonça JM. Revisão do gênero Seuratia Skrjabin, 1916 e redescrição da espécie Seuratia shipleyi (Stossich, 1900) Skrjabin, 1916 (Nematoda, Spiruroidea). Mem Inst Oswaldo Cruz 1967; 66(1): 117-129.

Sick H. Ornitologia Brasileira. Rio de Janeiro: Editora Nova Fronteira; 1997.

Spotorno B, Colabouno F, Barquete V, Vooren C. Lesiones causadas por nemátodeos en el proventrículo de procellariiformes en el litoral sur del Brasil [online]. 2005 [cited 2016 Oct 10]. Available from: http://www.schcm. cl/web/images/congresos/(25)\%20XXV\%20Congreso\%20de\%20\%20 Ciencias\%20del\%20Mar\%202005.pdf.

Vidal V, Ortiz J, Diaz JI, Zafrilla B, Bonete MJ, Ybañez MRR, et al. Morphological, molecular and phylogenetic analyzes of the spirurid nematode Stegophorus macronectes (Johnston \& Mawson, 1942). J Helminthol 2015; 90(2): 214-222. PMid:25871788. http://dx.doi. org/10.1017/S0022149X15000218.

Yoshimo T, Uemura J, Uematsu K, Tsuchida S, Osa Y, Taniyama H, et al. Postmortem and helminthological examination of seabirds killed by oilspilled at Ishikari, Hokkaido, Japan, in November 2004 [online]. 2015 [cited 2016 Oct 10]. Available from: http://gra.rakuno.ac.jp/wp-content/themes/ aplan/pdf/roh_201501.pdf 